\title{
Chalcone-Induced Apoptosis through Caspase-Dependent Intrinsic Pathways in Human Hepatocellular Carcinoma Cells
}

\author{
Rodrigo Ramirez-Tagle ${ }^{1}$, Carlos A. Escobar ${ }^{2}$, Valentina Romero ${ }^{1}$, Ignacio Montorfano ${ }^{1}$, \\ Ricardo Armisén ${ }^{3,4}$, Vincenzo Borgna ${ }^{5,6}$, Emanuel Jeldes 6,7, Luis Pizarro ${ }^{8}$, Felipe Simon ${ }^{9,10}$ \\ and Cesar Echeverria 1,3,*
}

1 Laboratorio de Bionanotecnologia, Universidad Bernardo O Higgins, General Gana 1780, Santiago 8370854, Chile; rramirez@ubo.cl (R.R.-T.); valentina.romero@ubo.cl (V.R.); montorfano3320@gmail.com (I.M.)

2 Departamento de Ciencias Químicas, Laboratorio de Síntesis Orgánica, Universidad Andres Bello, Av. República 275, Santiago 8370146, Chile; cescobar@unab.cl

3 Centro de Investigación y Tratamiento del Cancer, Facultad de Medicina, Universidad de Chile, Santiago 8380453, Chile; ricardoarmisen@med.uchile.cl

4 Center for Excellence in Precision Medicine Pfizer, Pfizer Chile, Obispo Arturo Espinoza Campos 2526, Macul, Santiago 7810305, Chile

5 Urology Department, Hospital Barros Luco Trudeau, San Miguel, Santiago 8900085, Chile; vborgna@gmail.com

6 Andes Biotechnologies SA and Fundación Ciencia para la Vida, Zañartu 1482, Nuñoa, Santiago 7780272, Chile; e.jeldes1@gmail.com

7 Department of Biological Science, Faculty of Biological Science, Universidad Andrés Bello, Santiago 8370146, Chile

8 Instituto Nacional del Cancer, Universidad de Chile, Profesor Zañartu 1010, Santiago 8380455, Chile; drluispizarro@gmail.com

9 Laboratorio de Fisiopatología Integrativa, Departamento de Ciencias Biologicas, Facultad de Ciencias Biologicas and Facultad de Medicina, Universidad Andres Bello, Avenida Republica 239, Santiago 8370146, Chile; fsimon@unab.cl

10 Millennium Institute on Immunology and Immunotherapy, Santiago 8331150, Chile

* Correspondence: cesar.echeverria@ubo.cl; Tel.: +56-22-477-2243

Academic Editor: Johannes Haybaeck

Received: 24 December 2015; Accepted: 1 February 2016; Published: 22 February 2016

\begin{abstract}
Hepatocellular carcinoma (HCC) is one of the most commonly diagnosed cancers worldwide. Chemoprevention of HCC can be achieved through the use of natural or synthetic compounds that reverse, suppress or prevent the development of cancer progression. In this study, we investigated the antiproliferative effects and the mechanism of action of two compounds, 2,3,4'-trimethoxy-2'-hydroxy-chalcone (CH1) and 3'-bromo-3,4-dimethoxy-chalcone (CH2), over human hepatoma cells (HepG2 and Huh-7) and cultured mouse hepatocytes (HepM). Cytotoxic effects were observed over the HepG2 and Huh-7, and no effects were observed over the HepM. For HepG2 cells, treated separately with each chalcone, typical apoptotic laddering and nuclear condensation were observed. Additionally, the caspases and Bcl-2 family proteins activation by using Western blotting and immunocytochemistry were studied. Caspase- 8 was not activated, but caspase- 3 and -9 were both activated by chalcones in HepG2 cells. Chalcones also induced reactive oxygen species (ROS) accumulation after 4, 8 and $24 \mathrm{~h}$ of treatment in HepG2 cells. These results suggest that apoptosis in HepG2 was induced through: (i) a caspase-dependent intrinsic pathway; and (ii) by alterations in the cellular levels of Bcl-2 family proteins, and also, that the chalcone moiety could be a potent candidate as novel anticancer agents acting on human hepatomas.
\end{abstract}

Keywords: Chalcone; Caspase; Reactive Oxygen Species 


\section{Introduction}

Hepatocellular carcinoma (HCC) is one of the most commonly occurring cancers in the world [1]. The incidence of HCC in Asia and Africa countries is 120 per 100,000; however, of 4 to 15 per 100,000 has been reported in Western countries [2]. Unfortunately, HCC is a relatively chemotherapy-resistant tumor mainly due to their heterogeneity and because of multidrug resistance phenotype's development [3]. Thus, current treatments available for liver cancer treatment remain unsatisfactory [4]. Apoptosis resistance, a hallmark of some human cancers, is tightly linked to the clinical cancer therapy failure, such as chemotherapy and radiotherapy [5,6]. Hepatocellular carcinoma (HCC) is one of the few cancers with well-defined major risk factors $[7,8]$. In $80 \%$ of cases, HCC develops in a cirrhotic liver, and cirrhosis is the strongest predisposing factor [7]. Genotoxic stress-induced apoptotic cell death by chemotherapy remains the primary anticancer treatment. However, despite the tremendous strides made in the development of targeted anticancer therapies, the prevalence of resistance to genotoxic drugs is still a major obstacle in the successful management of resistant and aggressive tumors [9-11]. Several studies have suggested a potential contribution of the reactive oxygen species (ROS) to oncogenesis and resistance to antitumor treatments [12,13]. Oxidative stress may also contribute to cancer initiation through ROS-induced DNA damage [14].

Conventional therapies for the treatment of hepatocarcinoma include, among others, chemotherapy, radiation, and surgical resection. Ablation fails to restore health because of insufficient diagnosis and serious side effects. Recently, an additional therapy has been introduced based on the application of antioxidants to decrease ROS-induced injury and to improve immunity function in rats suffering HCC $[15,16]$. Therefore, the development of more effective and less toxic chemoprevention agents is necessary to prevent or retard the process of hepatocarcinogenesis [17].

Chalcones (1,3-diaryl-2-propen-1-ones) are precursors in the biosynthesis of flavonoids/ isoflavonoids. Chemically, a chalcone consists of an open-chain flavonoid with two aromatic rings joined by a three-carbon $\alpha, \beta$-unsaturated carbonyl system $[18,19]$. Chalcones are reported to possess anti-inflammatory, antimicrobial, antioxidant and anticancer properties [19-23] and are components found spread in vegetables, and accessible to human consumption through a diet rich in fruits and vegetables.

The aim of this work is to determine the apoptotic and/or cytotoxic capabilities of two compounds, 2,3,4'-trimethoxy-2'-hydroxy-chalcone (CH1) and 3'-bromo-3,4-dimethoxy-chalcone (CH2), when acting over human hepatoma cells line (HepG2 and Huh-7). The present study also investigated the expression of caspase-8, caspase-9, caspase-3 and alterations in the cellular levels of Bcl-2 family proteins in HepG2 cells as well as the induction of ROS. Our results indicate that the two chalcones mediate the apoptosis in HepG2 cells in an intrinsic, caspase-dependent pathway, but also that they increase the presence of ROS. In contrast, they have no cytotoxic effects in cultivated primary mouse hepatocytes.

\section{Results}

\subsection{Cytotoxic Effect of Chalcones in Human Hepatoma Cells (HepG2) and Normal Mouse Hepatocytes (HepM)}

Once the primary culture of mouse hepatocytes (HepM) were obtained, we proceeded to confirm the culture purity by reverse transcription polymerase chain reaction (RT-PCR) and Western blotting. The mRNA expression of three hepato-specific markers [24,25], albumin, transferrin and Nuclear Factor $4 \alpha$ (HNF $4 \alpha$ ), were determined by RT-PCR. As shown in Figure 1, total RNA from primary cultured cells corresponding to the mRNAs of hepato-specific genes (lane 7, HepM) transcripts were amplified. These data demonstrate that our primary cultures are highly enriched in mouse hepatocytes. This result was compared with the amplification of these mRNAs in cell lines derived from human hepatomas (lane 3 and 5, Huh-7 and HepG2, respectively) and human keratinocytes (lane 1, HFK), where no amplification of these mRNAs was observed. Once the presence of hepatocytes in the 
primary culture was confirmed, we proceeded to analyze the purity of the culture. The constitutively expressed gene $18 \mathrm{~S}$ rRNA was used as an internal control.
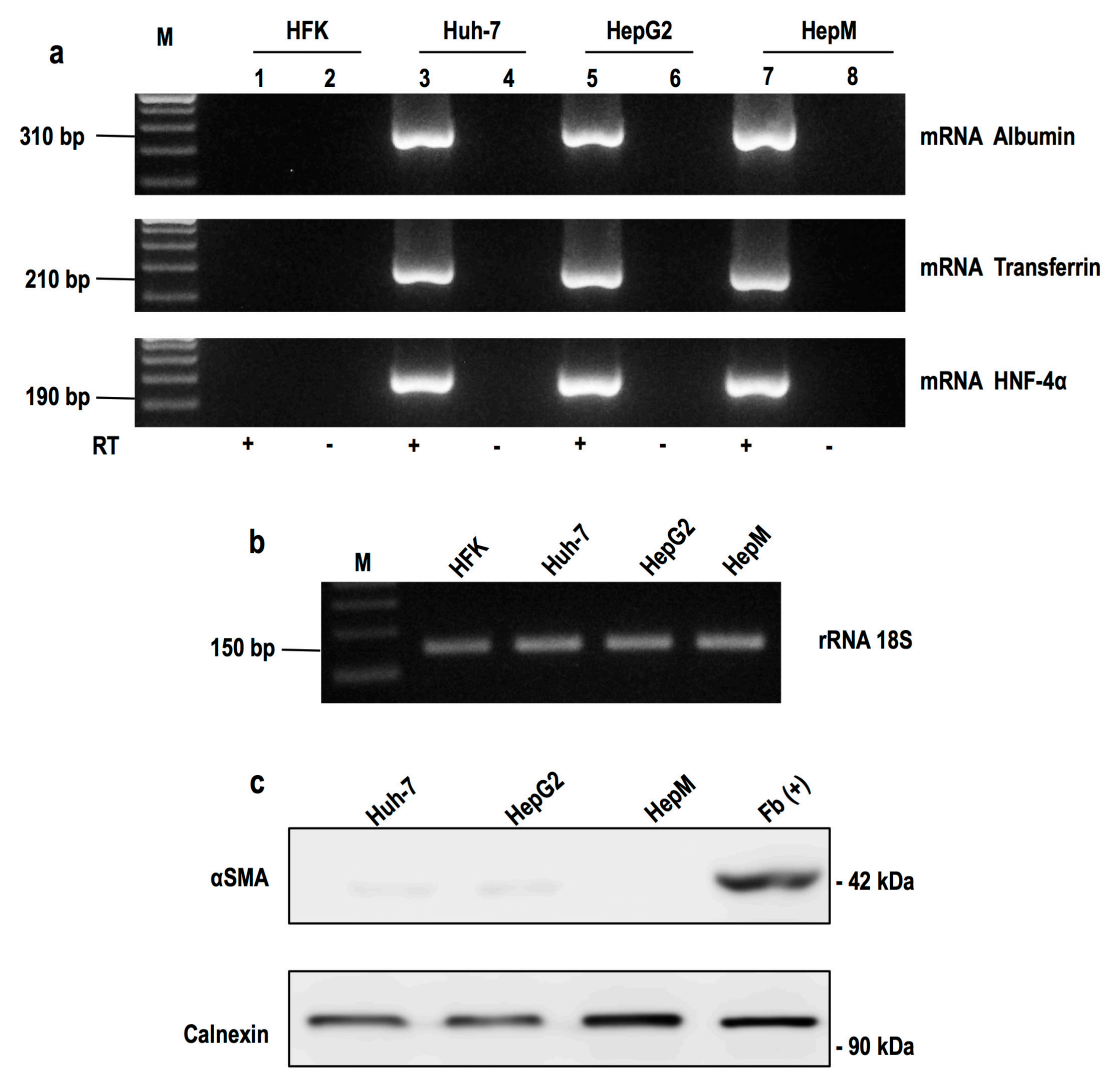

Figure 1. Expression of hepatic markers by RT-PCR and Western blot: (a) Markers of hepatic mRNAs were amplified. Electrophoresis agarose seen in the amplified fragments of 310, 210 and $190 \mathrm{bp}$, corresponding to albumin, transferrin and HNF- $4 \alpha$, respectively. The fragment was generated from the cDNA obtained from total RNA Huh-7, HepG2 and HEPM cells. Huh-7 and HepG2 cells were used as positive control. HFK cells were used as negative control. Reverse transcriptase in the absence of product is not detected (lanes 2, 4, 6, 8). M corresponds to the marking of $100 \mathrm{bp}$ molecular size; (b) Constitutively expressed gene 18S rRNA was used as an internal control; (c) Expression of the protein $\alpha$ SMA. By Western blot, the protein expression of $\alpha$ SMA was determined in the hepatic (Huh-7, HepG2 and HepM) and fibroblast cells (Fb (+)). Constitutively expressed calnexin was used as an internal control.

The presence of fibroblasts in the primary culture was determined by Western blot expression of $\alpha$-smooth muscle actin protein ( $\alpha \mathrm{SMA})$. As shown in Figure 1c, only the $\alpha \mathrm{SMA}$ was detected in the protein extract of fibroblasts (lane $\mathrm{Fb}(+)$ ), and it was not present in the extracts generated from the primary culture. This confirms that the primary culture is enriched with hepatocytes and not contaminated with fibroblasts.

The potential cytotoxic effect of the compounds $\mathrm{CH} 1$ and $\mathrm{CH} 2$ (Figure 2a) [26,27] were measured in HepG2, HuH-7 and HepM cells. As shown in Figure 2b-d, both chalcones had a cytotoxic effect only in HCC (HuH-7 and HepG2) cells, whereas cytotoxic effects were not observed in mouse hepatocytes (Figure 2e). Dose-response curve experiments were performed using both chalcones. $T$ he $I C_{50}$ for HepG2 cells is approximately $50 \mu \mathrm{M}$ at $24 \mathrm{~h}$ (Figure 2b) and close to $30 \mu \mathrm{M}$ (Figure 2c) at $48 \mathrm{~h}$ for both chalcones. A similar effect is observed in HuH-7 cells where both chalcones have an approximate $\mathrm{IC}_{50}$ of $30 \mu \mathrm{M}$ (Figure $2 \mathrm{~d}$ ) at $48 \mathrm{~h}$. No cytotoxic effects were observed in mouse hepatocytes with the same doses at $48 \mathrm{~h}$ (Figure 2e). 
a

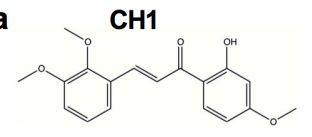
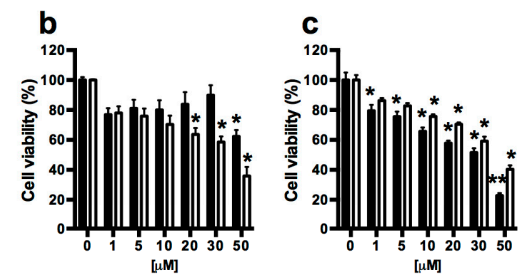
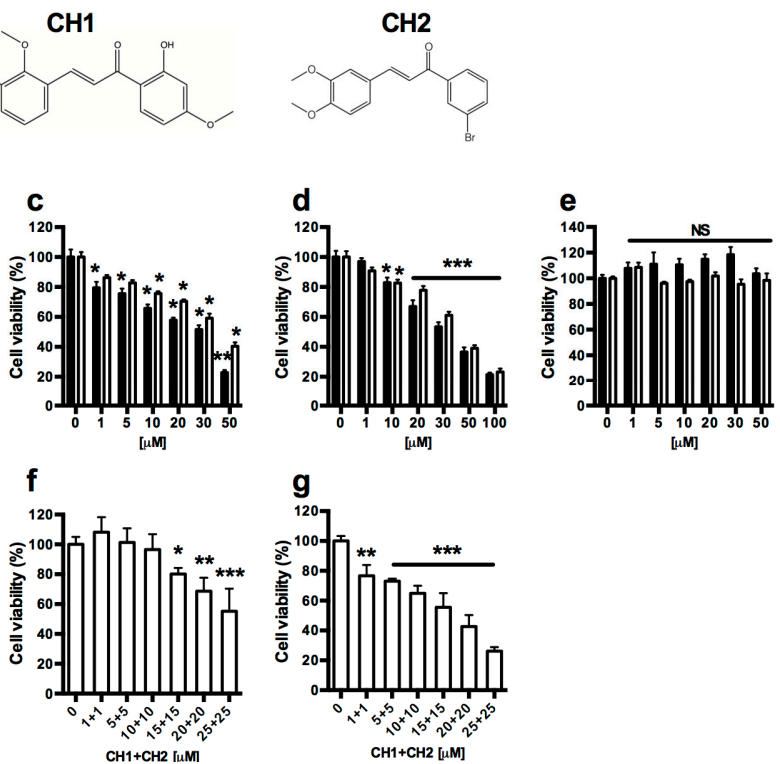

Figure 2. Effect of the chalcones $\mathrm{CH} 1$ and $\mathrm{CH} 2$ on the growth of human hepatocellular carcinoma (HepG2 and HuH-7) and normal mouse hepatocyte (HepM). Structures of CH1 and CH2 (a); HepG2 (b,c); HuH-7 (d) and HepM (e) were treated with various concentrations of the compounds CH1 (Black bars) and $\mathrm{CH} 2$ (White bars) for $24(\mathbf{b})$ and 48 (c-e) h. Chalcones combined (CH1:CH2) were used in HepG2 (f) and HuH-7 (g) cells for 48 h. Cell viability was measured using the MTT assay. Data are expressed as the mean \pm SEM from three independent experiments, each performed in triplicate. Statistical differences were assessed by a one-way ANOVA (Kruskal-Wallis) followed by Dunn's post hoc test. ${ }^{*} p<0.05,{ }^{* *} p<0.01,{ }^{* * *} p<0.001$ compared with the condition $0 \mu \mathrm{M}, \mathrm{NS}$, Non-significant.

Synergistic effects of combination treatment with both chalcones were studied in HepG2 (Figure 2f) and HuH-7 (Figure 2g) cells at $48 \mathrm{~h}$. There is no synergistic effect of both chalcones on HCC cells: the $I C_{50}$ (approximately $30 \mu \mathrm{M}$ ) is very similar to that observed with chalcones used separately.

HepG2 cells and mouse hepatocytes show similar intracellular accumulation of chalcones, whereas cells treated with the vehicle did not exhibit green fluorescence (Figure 3a,d). Cells treated with chalcones for 24 and $48 \mathrm{~h}$ show intracellular green marks that are attributed to the presence of the chalcone $\mathrm{CH} 1$ (Figure 3b,e) and CH2 (Figure 3c,f). These results demonstrate that both chalcones enter the cells independently.
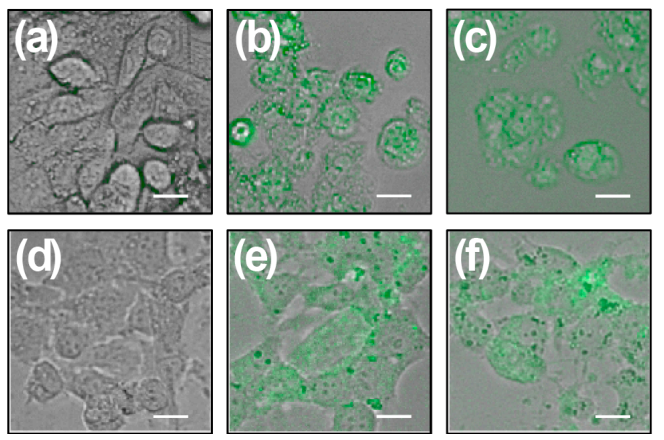

Figure 3. HepG2 and HepM cells exposed to chalcones $\mathrm{CH} 1$ and $\mathrm{CH} 2$. HepG2 and HepM cells were grown for $24 \mathrm{~h}$, and then treated with each chalcone, independently. Figures show representative phase-contrast images from at least three separates experiments of HepG2 (a-c) and HepM (d-f) exposed to vehicle (control) (a,d); $50 \mu \mathrm{M} \mathrm{CH1}$ (green) (b,e); and $50 \mu \mathrm{M} \mathrm{CH} 2$ (green) (c,f). Bar scale represents $10 \mu \mathrm{m}$. 


\subsection{Both Chalcones Induces Apoptosis in Human Hepatoma through Caspase-Dependent Pathways}

The presence of a laddered DNA fragmentation pattern, typical of apoptotic cells, was evaluated in HepG2 after $24 \mathrm{~h}$ of exposure to both chalcones (Figure 4). The chalcone $\mathrm{CH} 1$ and $\mathrm{CH} 2$ induced DNA fragmentation at a dose of $50 \mu \mathrm{M}$ (Figure 4a, lane 3 and 4), whereas the addition of a caspase inhibitor (zVAD) blocked the DNA fragmentation induced by both chalcones (Figure 4a, lane 5 and 6). Cells treated with DMSO, an inducer of apoptosis, provided a positive control for ladder formation [28] (Figure 4a, lane 8). Cells stained with 4'-6-diamidino-2-phenylindole (DAPI) showed high nuclear condensation in HepG2 cells treated for $24 \mathrm{~h}$ with CH1 (Figure 4b(ii)) and CH2 (Figure 4b(iii)). HepM cells did not show nuclear condensation with either chalcone (Figure $4 b(v, v i)$ ) and did not present differences from the control cells (Figure $4 \mathrm{~b}(\mathrm{i}, \mathrm{iii})$ ). According to the results obtained with ladder fragmentation and nuclear condensation, the next experiment was performed to quantify apoptotic cells. Flow cytometry was used to measure Annexin V-FITC and PI stained cells, which confirmed the induction of apoptosis in human hepatoma cells with both chalcones (Figure 5). As expected, both compounds increased the number of apoptotic cells. $1.7 \%$ of human hepatoma cells that were treated with vehicle were in the late stage of apoptosis and $2.6 \%$ were early in apoptosis (Figure $4 a(i)$ ), whereas cells that were treated for $24 \mathrm{~h}$ with the chalcones $\mathrm{CH} 1$ and $\mathrm{CH} 2$ exhibited an increase in late apoptosis of $43.6 \%$ and $40.7 \%$, respectively (Figure 5a(ii,iii)). Moreover, $\mathrm{CH} 1$ and $\mathrm{CH} 2$ exhibited an increase of early apoptotic cells of $16.9 \%$ and $8.7 \%$, respectively (Figure 5a(ii,iii)).

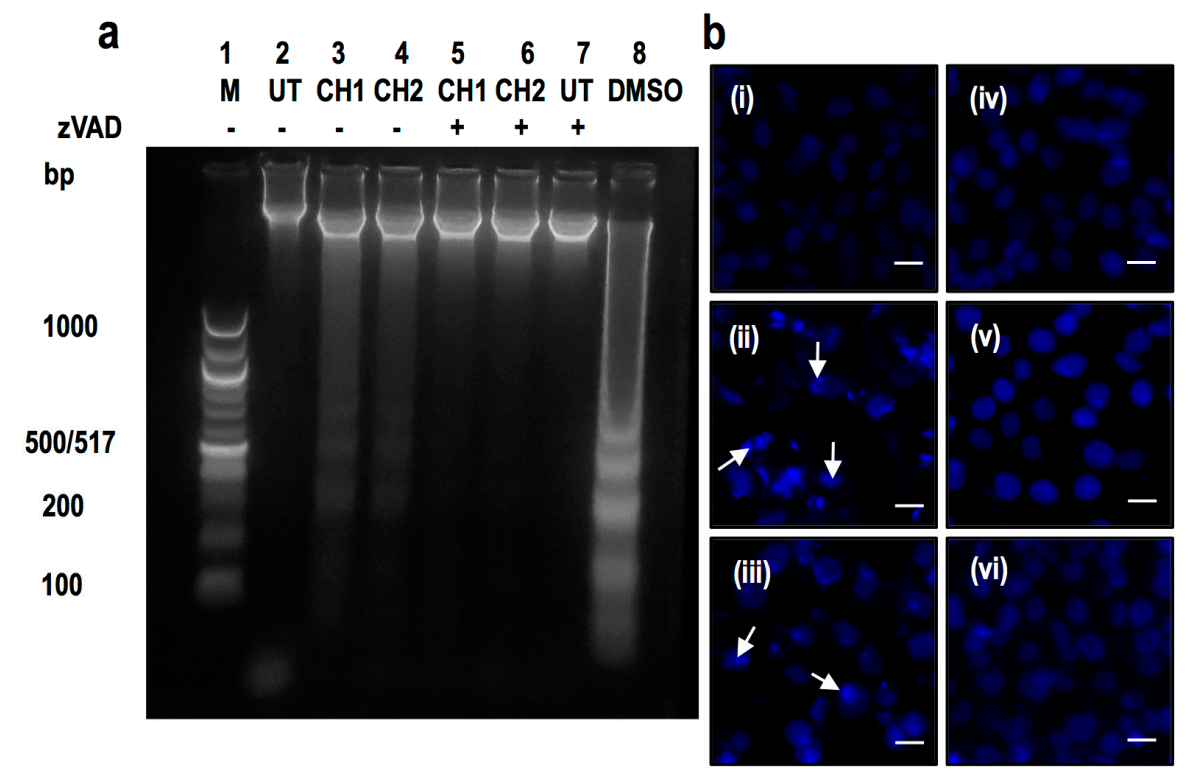

Figure 4. Chalcones induced laddering and nuclear condensation of HepG2 cells a process that requires caspase activity. (a) Cells were treated with $\mathrm{CH} 1$ and $\mathrm{CH} 2(50 \mu \mathrm{M})$ for $24 \mathrm{~h}$ and preincubated with $\mathrm{zVAD}(50 \mu \mathrm{M})$ for $2 \mathrm{~h}($ case +$)$, when the cells were incubated in the absence of inhibitor (case -), typical laddering indicative of apoptosis was observed. DMSO was used as control positive of laddering; (b) HepG2 (i-iii) and HepM (iv-vi) cells were treated with vehicle (i,iv), CH1 (ii,v) and CH2 (iii,vi) for $24 \mathrm{~h}$. Cells were stained with DAPI (blue) and the arrow indicated nuclear condensation. Bar scale represents $10 \mu \mathrm{m}$.

As shown in Figure $5 b$, significant differences were found between populations of live $(27.7 \% \pm 3.6 \%$, $55.0 \% \pm 10.7 \% ; p<0.05)$ and apoptotic $(39.3 \% \pm 3.8 \%, 35.4 \% \pm 5.5 \% ; p<0.01)$ human hepatoma cells treated with $\mathrm{CH} 1$ and $\mathrm{CH} 2$, respectively. However, only treatment with $\mathrm{CH} 1$ resulted in significant differences in early apoptosis $(14.6 \% \pm 1.2 \% ; p<0.05)$. These results demonstrated that both chalcones stimulate human hepatoma cells to initiate apoptosis, a process that requires caspase activity. 


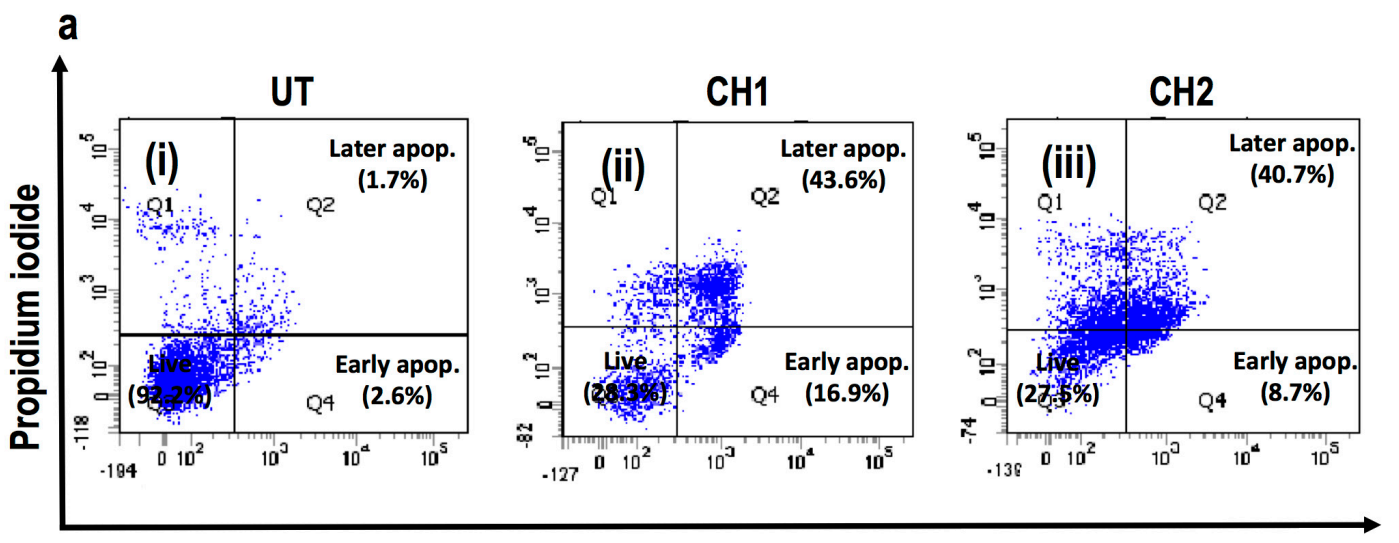

\section{Annexin V-Alexa Fluor 488}

\section{b}

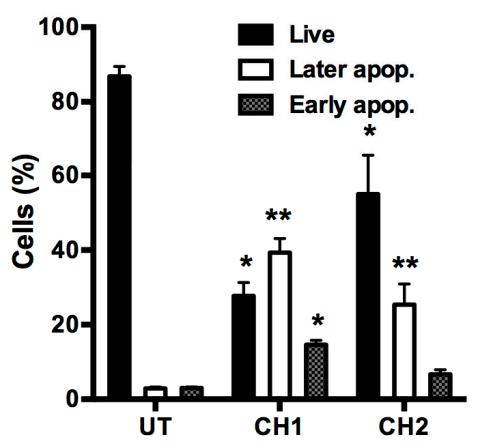

Figure 5. Chalcone-induced apoptosis in HepG2 cells as assayed by flow cytometry. (a) HepG2 cells were treated with $\mathrm{CH} 1$ and $\mathrm{CH} 2(50 \mu \mathrm{M})$ for $24 \mathrm{~h}$. The cells were then harvested and stained with Annexin V and PI and flow cytometric analysis was performed to analyze the apoptosis; (b) Summary of the apoptosis data in histogram form. Data are expressed as the mean \pm standard error of the mean (SEM) from at least three independent experiments. ${ }^{*} p<0.05$ vs. the untreated (UT) group; ${ }^{* *} p<0.01$ vs. the untreated group.

\subsection{Chalcones Induces Cell Death through an Intrinsic Apoptotic Pathway}

Caspase proteins play a major role in the activation of apoptosis. For this reason, both extrinsic and intrinsic activation pathways by caspases were analyzed in HepG2 cells treated with both chalcones. The extrinsic and intrinsic pathways of caspase activation were determined by Western blot analysis of the caspase-3, -8 and -9 activities, and also by the pro-apoptotic protein Bax and anti-apoptotic protein Bcl-2. The activity of the caspase 8 protein (extrinsic pathway) in HepG2 cells did not show any increase in the presence of both chalcones (Figure 6a-d). The total amount of the cleaved caspase-9 (C-caspase-9) protein (intrinsic pathway) increased significantly $(p<0.05)$ at 4 and $8 \mathrm{~h}$ (Figure $7 \mathrm{a}, \mathrm{b})$, whereas the total cleaved caspase-3 (C-caspase-3) protein level significantly increased $(p<0.01)$ at $8 \mathrm{~h}$ in HepG2 cells treated with $\mathrm{CH} 1$ (Figure 7c,d). Similar results were observed after treatment with $\mathrm{CH} 2$, where the $\mathrm{C}$-caspase-9 protein (intrinsic pathway) total significantly increased $(p<0.05)$ at $4 \mathrm{~h}$ (Figure $7 \mathrm{e}, \mathrm{f})$, whereas the C-caspase-3 protein total significant increased $(p<0.01)$ at 8 and $24 \mathrm{~h}$ in HepG2 cells treated with $\mathrm{CH} 2$ (Figure $7 \mathrm{~g}, \mathrm{~h}$ ). The data coincided with a significant increase in the Bax protein $(p<0.05)$ at 8 and $24 \mathrm{~h}$ (Figure $8 \mathrm{a}, \mathrm{b}, \mathrm{e}, \mathrm{f})$ and a significant decrease in the Bcl-2 protein $(p<0.01)$ at $24 \mathrm{~h}$ (Figure $8 \mathrm{c}, \mathrm{d}, \mathrm{g}, \mathrm{h})$ in HepG2 cells treated with $\mathrm{CH} 1$ and $\mathrm{CH} 2$, respectively. Densitometric analysis revealed significant increase of Bax/Bcl-2 ratio at $24 \mathrm{~h}$ with $\mathrm{CH} 1$ and 8 and $24 \mathrm{~h}$ with $\mathrm{CH} 2$ (Figure 8i,j). These results demonstrated that both chalcones induce apoptosis through the intrinsic caspase pathway. 

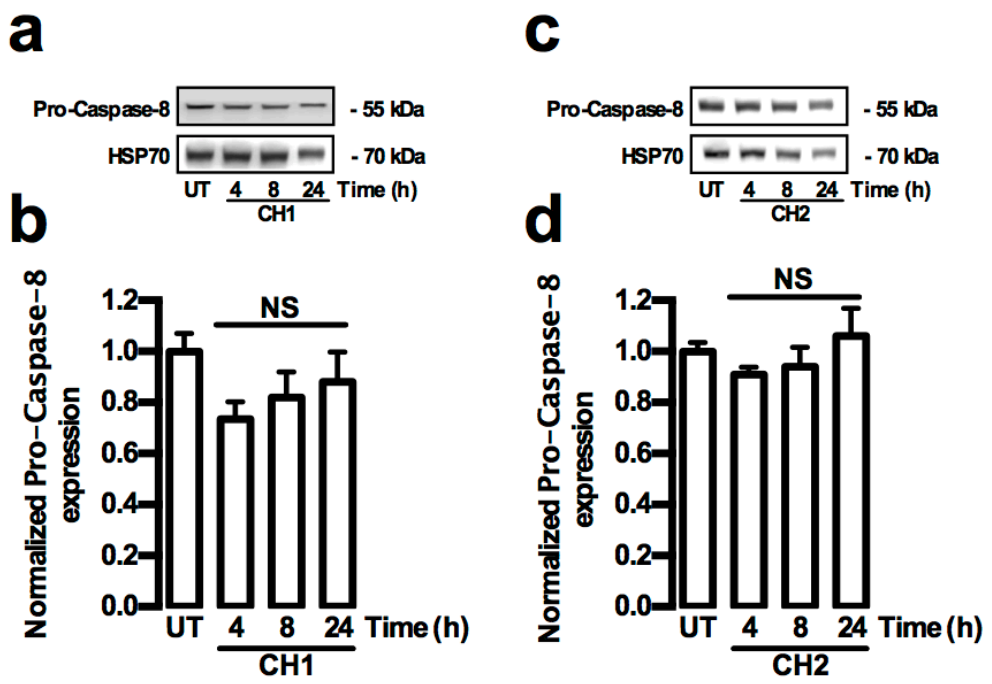

Figure 6. Chalcones do not induce caspase extrinsic pathway in HepG2 cells. (a-d) Cells were treated with $\mathrm{CH} 1$ and $\mathrm{CH} 2(50 \mu \mathrm{M}$, each) and protein expression was analyzed. (a,c) Representative images from Western blot experiments performed for the detection of caspase-8; (b,d) Densitometric analyses of the experiments shown in $(\mathbf{a}, \mathbf{c})$, respectively. Protein levels were normalized against HSP70 and data are expressed relative to the UT (untreated) condition. Data are expressed as the mean \pm standard error of the mean (SEM) from at least three independent experiments. Statistical differences were assessed by a one-way ANOVA (Kruskal-Wallis) followed by Dunn's post hoc test. NS: Not significant.

a
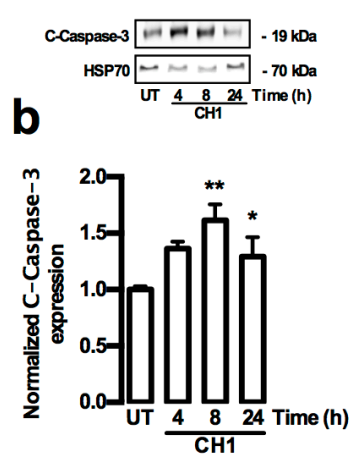

C
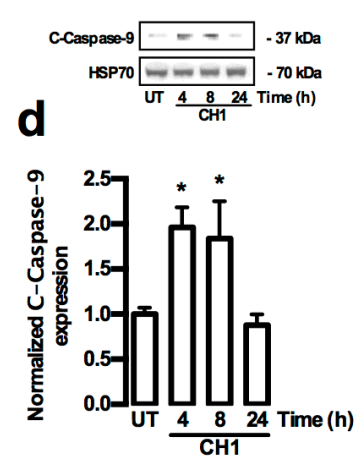

e
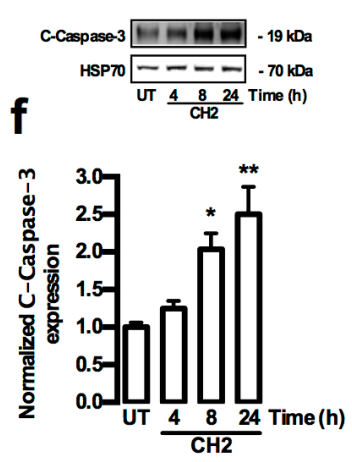

g
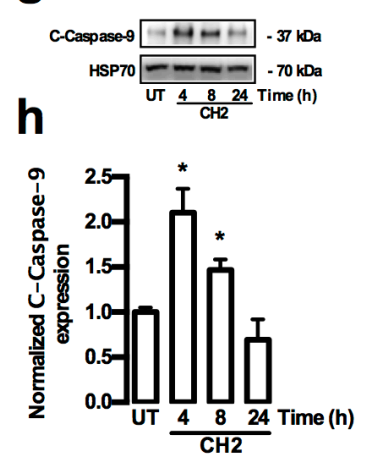

Figure 7. Chalcones-induced caspase intrinsic pathway in HepG2 cells. (a-h) Cells were treated with $\mathrm{CH} 1$ and $\mathrm{CH} 2(50 \mu \mathrm{M}$, each) and protein expression was analyzed. (a,c,e,g) Representative images from Western blot experiments performed for the detection of C-caspase-9 and C-caspase-3; $(\mathbf{b}, \mathbf{d}, \mathbf{f}, \mathbf{h})$ Densitometric analyses of the experiments shown in $(\mathbf{a}, \mathbf{c}, \mathbf{e}, \mathbf{g})$, respectively. Protein levels were normalized against HSP70 and data are expressed relative to the UT (untreated) condition. Data are expressed as the mean \pm standard error of the mean (SEM) from at least three independent experiments. Statistical differences were assessed by a one-way ANOVA (Kruskal-Wallis) followed by Dunn's post hoc test. ${ }^{*} p<0.05 ;{ }^{* *} p<0.01$ vs. UT group.

Immunocytochemistry analyses were also performed. HepG2 cells were treated with CH1 (50 $\mu \mathrm{M})$ for $24 \mathrm{~h}$ (Figure 8), and the cells were then fixed with 3.7\% paraformaldehyde prior to the detection of caspase- 3 and Bcl-2 protein expression. The results revealed that $\mathrm{CH} 1$ increased caspase- 3 expression (Figure 9a) and decreased Bcl-2 expression (Figure 9b) in HepG2 cells. Similarly, the CH2 compound increased caspase-3 expression (Figure 10a) and decrease Bcl-2 expression (Figure 10b). These findings also suggest that both chalcones induce the apoptosis of HepG2 in vitro. 
a

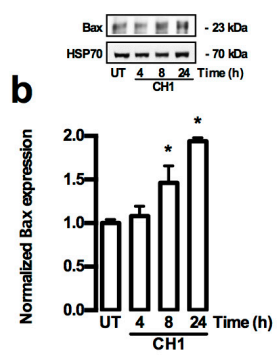

C

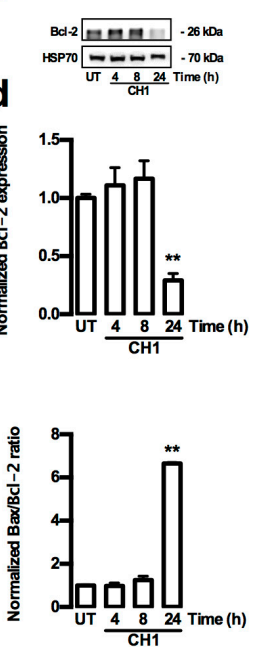

e
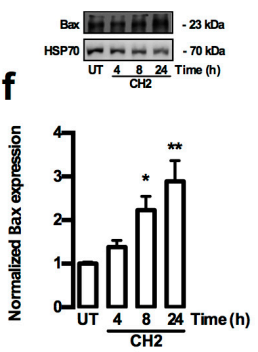

j

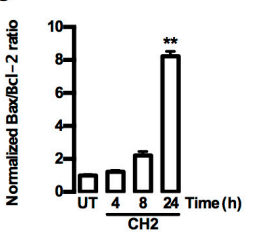

g
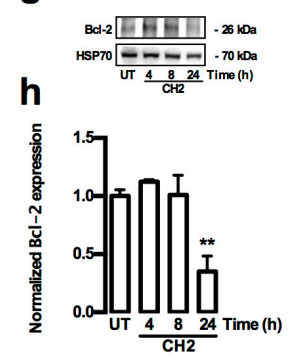

Figure 8. Chalcones-induced increase ratio Bax/Bcl-2 in HepG2 cells. (a-h) Cells were treated with $\mathrm{CH} 1$ and $\mathrm{CH} 2(50 \mu \mathrm{M}$, each) and protein expression was analyzed; (a,c,e,g) Representative images from Western blot experiments performed for the detection of Bax and Bcl-2; (b,d,f,h) Densitometric analyses of the experiments shown in $(\mathbf{a}, \mathbf{c}, \mathbf{e}, \mathbf{g})$, respectively. $(\mathbf{i}, \mathbf{j})$ the data were presented in the bar graphs as Bax/Bcl-2 ratio. Protein levels were normalized against HSP70 and data were expressed relative to the UT (untreated) condition. Data are expressed as the mean \pm standard error of the mean (SEM) from at least three independent experiments. Statistical differences were assessed by a one-way ANOVA (Kruskal-Wallis) followed by Dunn's post hoc test. ${ }^{*} p<0.05 ;{ }^{* *} p<0.01$ vs. UT group.

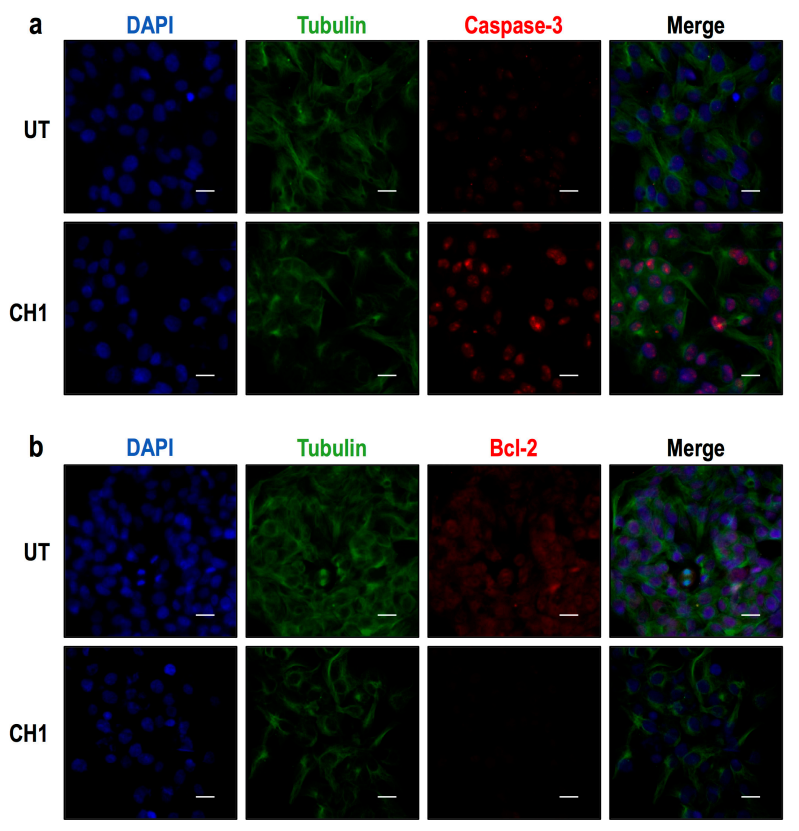

Figure 9. Protein expression of caspase-3 and Bcl-2 in HepG2 cells as shown by immunocytochemical analysis. HepG2 cells were treated with $50 \mu \mathrm{M}$ of $\mathrm{CH} 1$ for $24 \mathrm{~h}$, and then immunocytochemical analyses were performed as described in Materials and Methods. Cells were fixed and immunostained with anti-tubulin antibody (green), anti-caspase-3 (red) and cell nuclei were counterstained with DAPI reagent (blue). (a) The results revealed that $\mathrm{CH} 1$ increased caspase-3 expression in HepG2 cells; (b) $\mathrm{CH} 1$ was shown to decrease Bcl-2 expression in HerpG2 cells. These findings also suggest that $\mathrm{CH} 1$ induces the apoptosis of HepG2 cells in vitro. Tubulin was used as expression control. Bar scale represents $20 \mu \mathrm{m}$. 

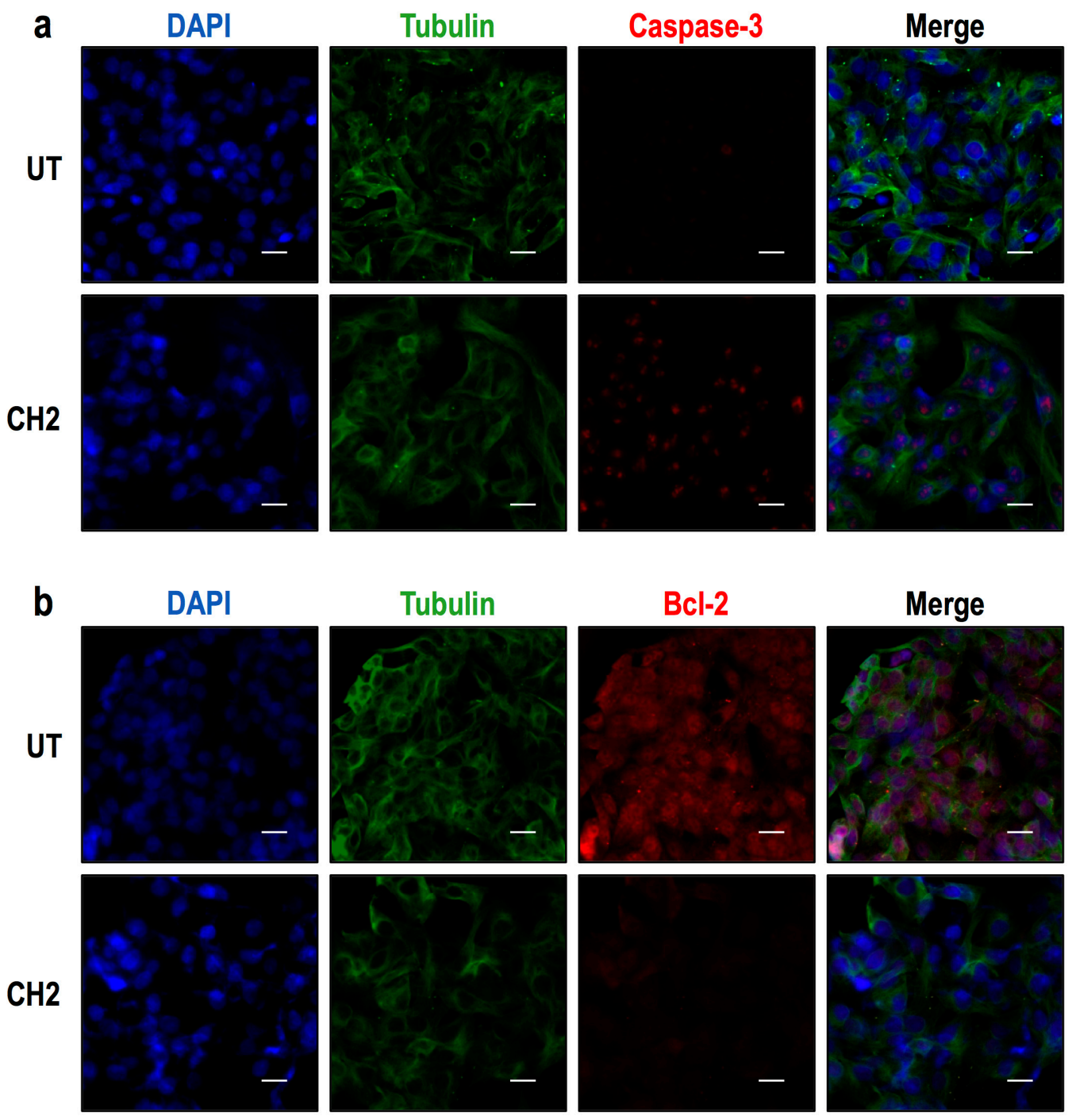

Figure 10. Protein expression of caspase- 3 and Bcl-2 in HepG2 cells as shown by immunocytochemical analysis. Cells were treated with $50 \mu \mathrm{M}$ of $\mathrm{CH} 2$ for $24 \mathrm{~h}$, and then immunocytochemical analyses were performed as described in Materials and Methods. Cells were fixed and immunostained with anti-tubulin antibody (green), anti-caspase-3 (red) and cell nuclei were counterstained with DAPI reagent (blue). (a) The results revealed that $\mathrm{CH} 2$ increased caspase-3 expression in HepG2 cells; (b) $\mathrm{CH} 2$ was shown to decrease Bcl-2 expression in HerpG2 cells. These findings also suggest that $\mathrm{CH} 2$ induces the apoptosis of HepG2 cells in vitro. Tubulin was used as expression control. Bar scale represents $20 \mu \mathrm{m}$.

\subsection{Chalcones Lead to Increased ROS}

To analyze the levels of hydrogen peroxide in HepG2 cells treated with both chalcones, we used a fluorescent probe, DCFDA, to detect ROS. Increased ROS levels were observed in HepG2 cells treated with both compounds, together with an early and late rise in ROS. As Figure 11a shows, 4 to $24 \mathrm{~h}$ after treatment, an increase in mean of RFU of cells treated with both chalcones were observed; RFU increased to $237 \%$ for $\mathrm{CH} 1$ and $276 \%$ for $\mathrm{CH} 2$ at $4 \mathrm{~h}, 291 \%$ for $\mathrm{CH} 1$ and $272 \%$ for $\mathrm{CH} 2$ at $8 \mathrm{~h}$, and $373 \%$ for $\mathrm{CH} 1$ and $482 \%$ for $\mathrm{CH} 2$ at $24 \mathrm{~h}$ in comparison to the untreated group. Consistent with the cytosolic fraction observations, we also observed an increase in the ROS levels by microscopy in HepG2 cells exposed to both chalcones (Figure 11b). 


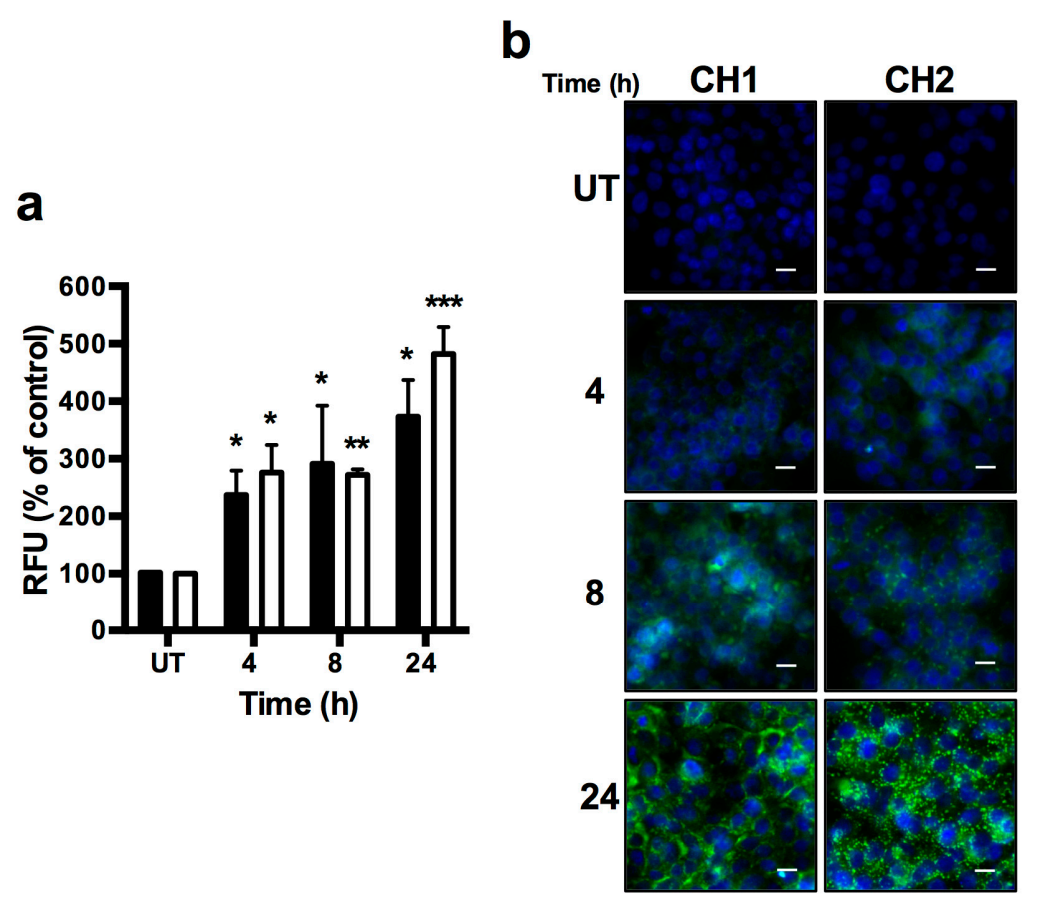

Figure 11. Chalcone effects on the HepG2 cells; Intercelular reactive oxygen species generation. $\mathrm{CH} 1$ and $\mathrm{CH} 2$ enhanced cellular ROS level. Cells were exposed to $\mathrm{CH} 1$ and $\mathrm{CH} 2$ at $50 \mu \mathrm{M}$ for 4, 8 and $24 \mathrm{~h}$. (a) Stained cells with DCFDA and analyzed by fluorescence in a plate reader (Tecan infinite ${ }^{\circledR}$ m200pro, Grodig, Austria); (b) Stained cells with DAPI (blue) and DCFDA (green), and analyzed under fluorescent microscopy EVOS ${ }^{\circledR}$ FLoid $^{\circledR}$ cell (Life Tehnologies, CA, USA), Black bars represents $\mathrm{CH} 1$ and White bars represents $\mathrm{CH} 2$. Data are expressed as the mean \pm standard error of the mean (SEM) from three independent experiments, each performed in triplicate. Statistical differences were assessed by a one-way ANOVA (Kruskal-Wallis) followed by Dunn's post hoc test. ${ }^{*} p<0.05$; ${ }^{* *} p<0.01$; *** $p<0.001$ vs. Untreated (UT) group. Bar scale represents $20 \mu \mathrm{m}$.

\section{Discussion}

In recent decades, many efforts have been made to develop drugs for cancer treatment based on the ability to block cell proliferation and/or induce apoptosis [29]. Apoptosis is a form of physiological cell death that is essential for normal tissue development and homeostasis [30,31]. This process can clearly be identified by characteristic changes in the cells (i.e., caspase activation, DNA fragmentation, cell fragmentation through the formation of "apoptotic bodies") [32]. Chalcones, considered as the precursors of many biologically important heterocycles (i.e., flavonoids, isoflavonoids, benzothiazepine, pyrazolines and 1,4-diketones). Thus, the synthesis of new chalcone derivatives is of great interest for medicinal chemists, especially because Chalcones have demonstrated to be very active against different cancer cell lines [33,34]. Human hepatomas are a major contributor to cancer deaths worldwide. Many efforts have been made to reduce the use of chemotherapy and introduce alternative chemicals that could help to improve the patient's quality of life. Chalcones have been widely studied due to their capacity to generate anti-tumor effects in a variety of cancers [33-37], and great efforts have been made to use chalcones to improve treatments for hepatic cancer [19,38-40].

The aim of our study is to identify novel compounds (i.e., chalcones) that activate apoptosis in hepatome and have low (or no) toxicity against liver cells. However, to consider chalcones as an anti-tumoral, the present study needs to be verified by further extensive in vivo testing.

We found that both chalcones, $\mathrm{CH} 1$ and $\mathrm{CH} 2$ generate cytotoxicity in human hepatome cells (HepG2) but not in normal hepatic cells (HepM). The induction of apoptosis in HepG2 cells is caspase-dependent and acts through the intrinsic pathway to generate fragmentation and nuclear condensation and increased levels of ROS. 
Other researchers have also reported the use of chalcones for the potential treatment of HCC [41,42], but its effect was not demonstrated in normal hepatic cells. Many efforts have been made to synthesize compounds that destroy only the hepatoma, causing no damage to normal hepatic cells $[42,43]$. In this work, for the first time, we document the application of two chalcones in hepatic tumor cells. Our results showed that $\mathrm{CH} 1$ and $\mathrm{CH} 2$ have some effect on hepatic tumor cells and have no cytotoxic effect on normal hepatic cells (Figure 2). We have previously reported that chalcones exerts a cytotoxic effects in HepG2 cells [19] $\left(I C_{50}>100 \mu \mathrm{M}\right)$. However, researchers have recently reported that another group of chalcones have $I C_{50}$ similar to $\mathrm{CH} 1$ and $\mathrm{CH} 2$ in HepG2 cells [44] $\left(I C_{50}<50 \mu \mathrm{M}\right)$. Although the $I C_{50}$ of these chalcones is high, other chalcones have similar cytotoxic effect in a variety of tumors [45-48]. Both chalcones ( $\mathrm{CH} 1$ and $\mathrm{CH} 2)$ tested induced cytotoxicity through caspase-dependent apoptosis (Figures 3 and 4). As previously documented, chalcones can activate intrinsic and extrinsic pathways $[29,49]$. Taking this evidence into account, the activity of caspase-8 (Figure 5a-d), caspase-9 (Figure $6 \mathrm{a}, \mathrm{b}, \mathrm{e}, \mathrm{f}$ ) and caspase-3 (Figure $6 \mathrm{c}, \mathrm{d}, \mathrm{g}, \mathrm{h}$ ) were analyzed. In our case, only caspase-3 and caspase- 9 were activated by both chalcones, demonstrating that the intrinsic pathway is crucial to induce apoptosis in HepG2 cells. To determine the location and distribution of caspase-3 (proapoptotic) and Bcl-2 (antiapoptotic) we performed immunocytochemistry assays. The results showed that both chalcones increased the presence of caspase-3 and also demonstrated that they are located mainly in the nucleus of HepG2 cells (Figures 8 and 9). This effect has already been observed by other researchers, indicating that caspase- 3 has a major role in the progression of apoptosis [50]. Furthermore, our studies showed that both chalcones resulted in an obvious decrease in the Bcl-2 protein expression and a notable increase in Bax protein production in the HepG2 cells (Figures 6 and 7). The Bcl-2 protein family includes proapoptotic members such as bax, bak, bad, bcl-xs, bid, bik, bim, and hrk, and antiapoptotic members such as bcl-2, bcl-xl, bcl-w, bfl-1, and mcl-1 [51-53]. Researchers have suggested that changes in ratio of Bax to Bcl-2 may contribute to the caspase-3 activation and the modulation of renal and neuronal apoptosis in rats [54,55]. Moreover, in HepG2 cells, it was demonstrated that the compound Xanthorrhizol decreased the regulation of the Bcl-2 protein but did not affect the Bax protein while activating caspase-3 and caspase-9. Xanthorrhizol exerts anti-proliferative effects on HepG2 cells by inducing apoptosis via the mitochondrial pathway [56]. The mitochondria are primarily responsible for the generation of intracellular ROS [57]. Increased ROS levels alter cellular function through the oxidation of amino acids in proteins, lipids, and DNA damage, which triggers apoptotic processes [58]. Our results show a progressive increase in ROS from 4 to $24 \mathrm{~h}$ with both chalcones (Figure 10a,b). Other research groups have reported increased ROS in different cell lines stimulated by chalcones [41,59]; and the antioxidant effect of chalcones has also been reported [60-63].

\section{Materials and Methods}

\subsection{Synthesis of Chalcone}

We have previously described the synthesis of the following compounds: 2,3,4'-trimethoxy2'-hydroxy-chalcone (CH1) [26] which was obtained as orange crystals (58\%), mp. $129-130^{\circ} \mathrm{C}$; and 3'-bromo-3,4-dimethoxy-chalcone (CH2) [27] obtained as yellow crystals (73\%), mp. $117-120{ }^{\circ} \mathrm{C}$ (Figure 1a).

\subsection{Cell Culture}

Human hepatocellular carcinoma HepG2 cells (American Type Culture Collection HB-8065) and Huh-7 were grown in monolayer culture in Dulbecco's modified Eagle Medium (DMEM) with 10\% fetal bovine serum (FBS) (Gibco, NY, USA) and antibiotic-antimycotic (Gibco, NY, USA) at $37^{\circ} \mathrm{C}$ in a humidified $5 \% \mathrm{CO}_{2}$ incubator.

Primary culture of mouse hepatocytes (HepM) were isolated from male BALB/C mice (three weeks old) using a modification of the perfusion and enzymatic digestion protocol as previously described [64]. Briefly, the liver was first perfused with liver perfusion buffer I 0.9\% 
$\mathrm{NaCl}$ (Merck, Darmstadt, Germany), $100 \mu \mathrm{g} / \mathrm{mL}$ gentamicin (Gibco, Grand Island, NY, USA), $2 \times$ antibiotic-antimycotic (Gibco, NY, USA), $0.2 \mathrm{mM}$ EGTA (Sigma, USA) to disrupt hepatocyte desmosomes. In order to separate hepatocytes from the extracellular matrix, a second perfusion was performed with liver perfusion buffer II 0.5\% collagenase I, II, IV (Gibco, Grand Island, NY, USA), $0.25 \%$ hyaluronidase (Sigma), 0.1\% Dispase (Gibco), 0.025\% DNase I (Gibco), 0.1\% BSA (Rockland, Limerick, PA, USA), $2 \times$ antibiotic-antimycotic (Gibco, Grand Island, NY, USA), 1 mM CaCl 2 (Sigma) in DMEM GlutaMaxTM (Gibco, Grand Island, NY, USA). The liver was then removed and cut in fine pieces, followed by three washes in PBS and incubated in liver perfusion buffer II at 250 RPM for $1 \mathrm{~h}$ at $37^{\circ} \mathrm{C}$. Then, the cells were centrifuged at $300 \times g$ for $5 \mathrm{~min}$, washed in PBS (as described before) and incubated with $4 \times$ trypsin at $250 \mathrm{RPM}$ for $15 \mathrm{~min}$ at $37^{\circ} \mathrm{C}$. The cells were centrifuged and washed (as described before) and incubated in lysis buffer $\left(8.3 \mathrm{~g} \mathrm{NH}_{4} \mathrm{Cl}, 1.0 \mathrm{~g} \mathrm{KHCO}, 5 \%\right.$ EDTA) at $250 \mathrm{RPM}$ for $10 \mathrm{~min}$ at $37^{\circ} \mathrm{C}$. Finally the hepatocytes were plated and cultured on collagen-coated tissue culture plate to $70 \%$ confluent and maintained in hepatocyte medium DMEM GlutaMax ${ }^{\mathrm{TM}}$ (Gibco, Grand Island, NY, USA): DMEM/F12 (Gibco, Grand Island, NY, USA) (1:1) supplemented with $1 \times$ Insulin-transferrin-selenium (Gibco, Grand Island, NY, USA), $5 \mu \mathrm{g} / \mathrm{mL}$ hydrocortisone (Sigma), 10\% FBS (Biological Industries, Kibbutz Beit-Haemek, Israel), $2 \times$ Antibiotic-Antimycotic (Gibco, Grand Island, NY, USA) and $20 \mathrm{mM}$ HEPES (Gibco, Grand Island, NY, USA) at $37{ }^{\circ} \mathrm{C}$ in $5 \% \mathrm{CO}_{2}$. HepG2 and HepM cells were treated with chalcones $\mathrm{CH} 1$ and $\mathrm{CH} 2$ diluted in Milli-Q water. The Milli-Q water was also used in the untreated control (UT).

\subsection{Ethics Approval}

This research was performed according to the "Guides for the Care and Use of Laboratory Animals" [65]. Mice were kept in cages with controlled light conditions (12 h light/darkness) and given food and water ad libitum. The use of these animals was approved by the "bioethics and biosafety committee" of Fundación Ciencia para la Vida. The maintenance of the animals was performed in the animal facility of Fundación Ciencia para la Vida. During the whole course of animal experiments, all efforts were made to minimize suffering.

\subsection{MTT Assay}

HepG2 cells were seeded in a 96-well plate at an initial density of $5 \times 103$ cells/well. Twenty-four hours later, the cells were treated with control (Milli-Q water) or various concentrations of chalcone for 24 and $48 \mathrm{~h}$. The MTT (3-(4,5-dimethyl-2-thiazolyl)-2,5-diphenyl-2H-tetrazolium bromide) method was used as we previously described [66]. The absorbance of the dissolved formazan crystals was measured at $540 \mathrm{~nm}$ using a microplate reader (Tecan infinite ${ }^{\circledR}$ f50, Grodig, Austria).

\subsection{Western Blot}

Western blot method was used as we previously described [67]. For a detailed list of antibodies used, see Table S1.

\subsection{Fluorescence Microscopy}

Fluorescence microscopy method was used as we previously described [67]. For a detailed list of antibodies used, see Table S2. Fluorescent cells were analyzed using the microscopy EVOS ${ }^{\circledR}$ FLoid ${ }^{\circledR}$ cell (Life Technologies, Carlsbad, CA, USA).

\subsection{Determination of Intracellular ROS}

2,7-Dichlorodihydrofluorescein diacetate (DCFH-DA), method was used as we previously described [68]. DCF fluorescence was detected by a fluorescence plate reader (Tecan infinite ${ }^{\circledR} \mathrm{m} 200$ pro). ROS levels were expressed as the relative fluorescence unity's (RFU) of DCF. Fluorescent cells were analyzed using the $\operatorname{EVOS}^{\circledR}$ FLoid $^{\circledR}$ cell (Life Technologies, Carlsbad, CA, USA). 


\subsection{Annexin-V Apoptosis Assay}

Apoptosis was measured through flow cytometry. Detection of phosphatidylserine expression on early apoptotic cells using fluorescein labeled Annexin-V using "Alexa Fluor 488 Annexin V/Dead Cell Apoptosis" Kit, the protocol was carried out as described by the manufacturer's instructions (Invitrogen, Carlsbad, CA, USA). The cells were analyzed in a flow cytometer model BD FACS Canto II and 10,000 events were analyzed by sample.

\subsection{DNA Laddering Experiments}

HepG2 cells were seeded in 6-well plates at a density of 105 per well and exposed to $50 \mu \mathrm{M}$ of chalcone for $24 \mathrm{~h}$. DNA laddering method was used as we previously described [69].

\subsection{RT-PCR Amplification}

Total RNA from cells was extracted with Trizol (Invitrogen) as described before [70]. To eliminate DNA contamination, RNA preparations were treated with TURBO DNA-freeTM (Ambion, Austin, TX, USA) according to the manufacturer's instructions. Reverse transcription was carried out with $100 \mathrm{ng}$ of freshly prepared RNA, 50 ng of random hexamers primers, and 100 units of reverse transcriptase (Moloney murine leukemia virus, Invitrogen) and 20 units of RiboLock (Thermo Scientific, Waltham, MA, USA) as described before [70]. The PCR-amplified were made in a volume of $50 \mu \mathrm{L}$ containing $1 \times$ Go Taq Flexi Buffer, $1.5 \mathrm{mM} \mathrm{MgCl} \mathrm{M}_{2}$, dNTPs $(0.4 \mu \mathrm{M}), 2.0 \mu \mathrm{L} \mathrm{cDNA}, 1.0 \mu \mathrm{M}$ of each primer and 2.5 units of Go Taq Flexi DNA Polymerase (Invitrogen). Standard conditions for amplification were as follows: initial denaturation step at $94{ }^{\circ} \mathrm{C}$ for $5 \mathrm{~min}$, then 30 cycles at $94{ }^{\circ} \mathrm{C}$ for $1 \mathrm{~min}$, then kept at $56{ }^{\circ} \mathrm{C}$ for $1 \mathrm{~min}, 72{ }^{\circ} \mathrm{C}$ for $1 \mathrm{~min}$, followed by a final extension step of $72{ }^{\circ} \mathrm{C}$ for $5 \mathrm{~min}$. The primers used to amplify the genes products of Transferrin, Albumin and HNF $4 \alpha$ were designed to recognize the Human and Mouse mRNA sequence. The primers used for amplification were the following: Transferrin mRNA, Transferrin (r) (5'-GTGCTTGACAAAGGCCACA) and Transferrin (f) (5'-AGGCAAGAAGTCCTGCCA), Albumin mRNA, Albumin (r) (5'-TGCCCAGGAAGACATCCTT) and Albumin (f) (5'-AAAGCATGGGCAGTAGCTC); HNF $4 \alpha$ mRNA, HNF $4 \alpha$ (r) (5'-ACCTGC TCTACCAGCCAGAA) and HNF $4 \alpha$ (f) (5'-GCAGGGTCTAGAAGGCTGTG). Amplified DNA fragments were analyzed by electrophoresis.

\subsection{Data Analysis}

In all experiments, replicates were made and the data presented represent the average \pm standard error (SEM) of at least three independent experiments performed in triplicate. The comparisons were conducted using one-way analysis of variance (ANOVA) (Kruskal-Wallis) followed by Dunn's post hoc test and considered significant at $p<0.05$.

\section{Conclusions}

Our results demonstrate that both chalcones have a cytotoxic effect on human hepatoma through the induction of caspase-dependent apoptosis. These chalcones activate intracellular ROS levels and could be responsible for the activation of programmed death, through the intrinsic mitochondrial pathway mediated by Bax/Bcl-2 and the modulation of caspase- 9 and caspase- 3 (Figure 12). Furthermore, neither chalcones have cytotoxic effects on normal mouse hepatocytes. This would allow the potential use of chalcones as a selective drug to target only tumor cells. Further experiments in vivo are needed to verify the possible application of chalcones as selective drugs for the treatment of cancer. 


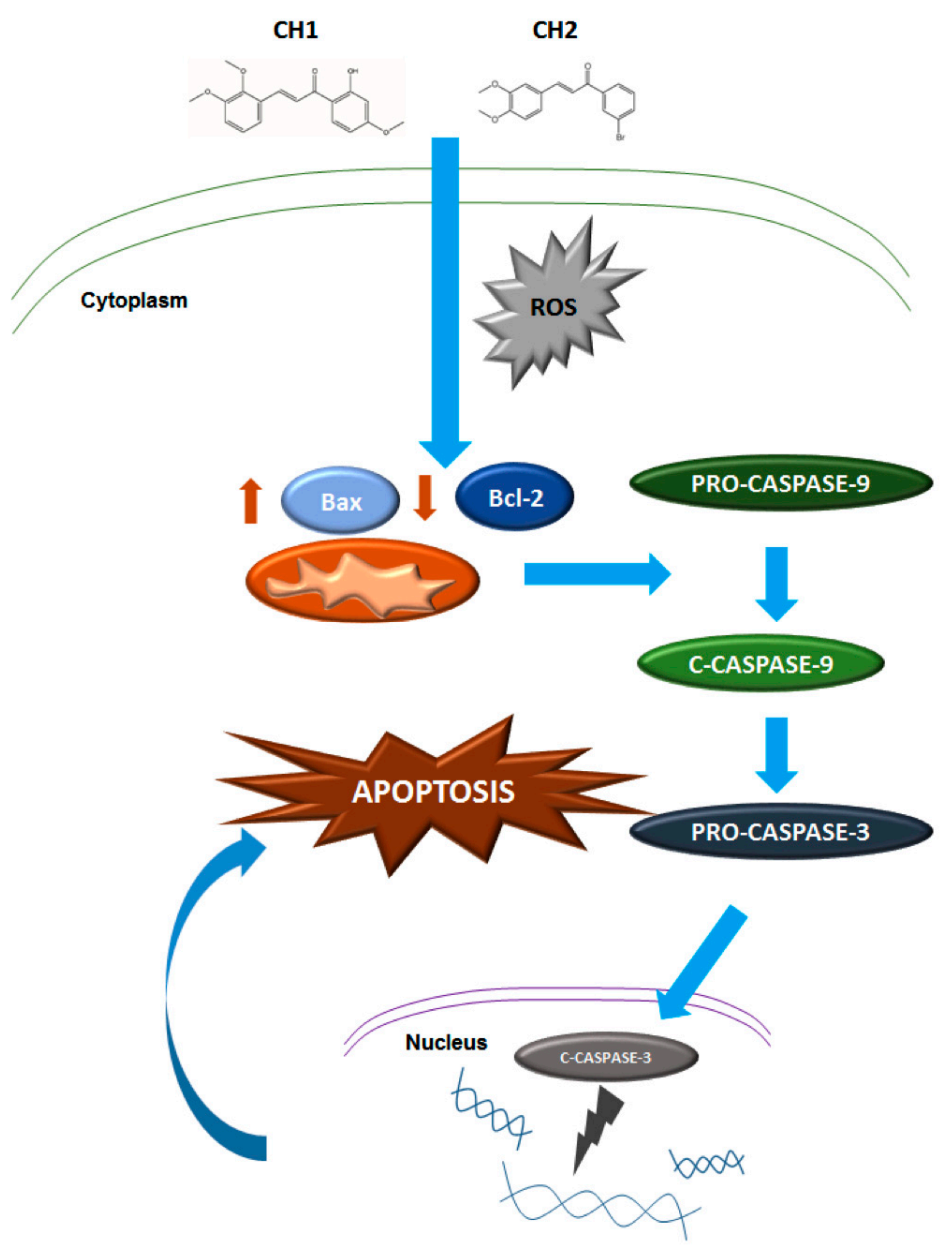

Figure 12. Proposed model for Chalcone-mediated apoptosis in human hepatoma cells. Solid arrow represent activation.

Supplementary Materials: Supplementary materials can be found at http:/ /www.mdpi.com/1422-0067/17/ 2/260/s1.

Acknowledgments: This work was supported by the research grants from Fondo Nacional de Desarrollo Científico y Tecnológico-Fondecyt 11130007 (R.R-T.), 1080147 (C.A.E), 3140448 (C.E.), 1121078 (F.S.), and 1151446 (R.A.); Anillo en Ciencia y Tecnologia ACT1115 (R.A.); Millennium Institute on Immunology and Immunotherapy P09-016-F (F.S.); and UNAB DI-741-15/N (F.S.).

Author Contributions: Rodrigo Ramirez-Tagle contributed with materials and analysis tools; Carlos A. Escobar synthesis, purification and spectroscopic characterization of chalcones; Valentina Romero, Ignacio Montorfano, Vincenzo Borgna, and Emanuel Jeldes performed the experiments; Ricardo Armisén and Luis Pizarro analyzed the data; Felipe Simon edited the manuscript; and Cesar Echeverria wrote the paper. All authors read and approved the final manuscript.

Conflicts of Interest: The authors declare no conflict of interest.

\section{References}

1. Ferlay, J.; Shin, H.R.; Bray, F.; Forman, D.; Mathers, C.; Parkin, D.M. Estimates of worldwide burden of cancer in 2008: GLOBOCAN 2008. Int. J. Cancer 2010, 127, 2893-2917. [CrossRef] [PubMed]

2. Witjes, C.D.M.; Karim-Kos, H.E.; Visser, O.; van den Akker, S.A.W.; de Vries, E.; Ijzermans, J.N.M.; de Man, R.A.; Coebergh, J.W.W.; Verhoef, C. Hepatocellular carcinoma in a low-endemic area: Rising incidence and improved survival. Eur. J. Gastroenterol. Hepatol. 2012, 24, 450-457. [CrossRef] [PubMed]

3. Shen, D.W.; Lu, Y.G.; Chin, K.V.; Pastan, I.; Gottesman, M.M. Human hepatocellular carcinoma cell lines exhibit multidrug resistance unrelated to MRD1 gene expression. J. Cell Sci. 1991, 98, 317-322. [PubMed] 
4. Honda, K.; Sbisa, E.; Tullo, A.; Papeo, P.A.; Saccone, C.; Poole, S.; Pignatelli, M.; Mitry, R.R.; Ding, S.; Isla, A.; et al. p53 mutation is a poor prognostic indicator for survival in patients with hepatocellular carcinoma undergoing surgical tumour ablation. Br. J. Cancer 1998, 77, 776-782. [CrossRef] [PubMed]

5. Mor, G.; Montagna, M.K.; Alvero, A.B. Modulation of apoptosis to reverse chemoresistance. Methods Mol. Biol. 2008, 414, 1-12. [PubMed]

6. Giménez-Bonafé, P.; Tortosa, A.; Pérez-Tomás, R. Overcoming drug resistance by enhancing apoptosis of tumor cells. Curr. Cancer Drug Targets 2009, 9, 320-340. [CrossRef] [PubMed]

7. Forner, A.; Llovet, J.M.; Bruix, J. Hepatocellular carcinoma. Lancet 2012, 379, 1245-1255. [CrossRef]

8. Bosch, F.X.; Ribes, J.; Borràs, J. Epidemiology of primary liver cancer. Semin. Liver Dis. 1999, 19, $271-285$. [CrossRef] [PubMed]

9. Gridelli, C.; Rossi, A.; Maione, P.; Ferrara, M.L.; Castaldo, V.; Sacco, P.C. Vaccines for the treatment of non-small cell lung cancer: A renewed anticancer strategy. Oncologist 2009, 14, 909-920. [CrossRef] [PubMed]

10. Connolly, E.C.; Saunier, E.F.; Quigley, D.; Luu, M.T.; De Sapio, A.; Hann, B.; Yingling, J.M.; Akhurst, R.J. Outgrowth of drug-resistant carcinomas expressing markers of tumor aggression after long-term T $\beta R I / I I$ kinase inhibition with LY2109761. Cancer Res. 2011, 71, 2339-2349. [CrossRef] [PubMed]

11. Li, Y.; Tan, B.B.; Zhao, Q.; Fan, L.-Q.; Liu, Y.; Hao, Y.-J.; Zhao, X.-F. Tumor chemosensitivity is correlated with expression of multidrug resistance associated factors in variously differentiated gastric carcinoma tissues. Hepatogastroenterology 2013, 60, 213-216. [CrossRef] [PubMed]

12. Efferth, T.; Giaisi, M.; Merling, A.; Krammer, P.H.; Li-Weber, M. Artesunate induces ROS-mediated apoptosis in doxorubicin-resistant T leukemia cells. PLoS ONE 2007, 2, e693. [CrossRef] [PubMed]

13. Bechtel, W.; Bauer, G. Catalase protects tumor cells from apoptosis induction by intercellular ROS signaling. Anticancer Res. 2009, 29, 4541-4557. [PubMed]

14. Wiseman, H.; Halliwell, B. Damage to DNA by reactive oxygen and nitrogen species: Role in inflammatory disease and progression to cancer. Biochem. J. 1996, 313, 17-29. [CrossRef] [PubMed]

15. Hassan, S.K.; Mousa, A.M.; Eshak, M.G.; Farrag, A.E.R.H.; Badawi, A.E.F.M. Therapeutic and chemopreventive effects of nano curcumin against diethylnitrosamine induced hepatocellular carcinoma in rats. Int. J. Pharm. Pharm. Sci. 2014, 6, 54-62.

16. Chen, B.; Ning, M.; Yang, G. Effect of paeonol on antioxidant and immune regulatory activity in hepatocellular carcinoma rats. Molecules 2012, 17, 4672-4683. [CrossRef] [PubMed]

17. Zhang, C.L.; Zeng, T.; Zhao, X.L.; Yu, L.H.; Zhu, Z.P.; Xie, K.Q. Protective effects of garlic oil on hepatocarcinoma induced by $N$-nitrosodiethylamine in rats. Int. J. Biol. Sci. 2012, 8, 363-374. [CrossRef] [PubMed]

18. Dimmock, J.R.; Elias, D.W.; Beazely, M.A.; Kandepu, N.M. Bioactivities of chalcones. Curr. Med. Chem. 1999, 6, 1125-1149. [PubMed]

19. Echeverria, C.; Santibañez, J.F.; Donoso-Tauda, O.; Escobar, C.A.; Ramirez-Tagle, R. Structural antitumoral activity relationships of synthetic chalcones. Int. J. Mol. Sci. 2009, 10, 221-231. [CrossRef] [PubMed]

20. Katsori, A.-M.; Hadjipavlou-Litina, D. Chalcones in cancer: Understanding their role in terms of QSAR. Curr. Med. Chem. 2009, 16, 1062-1081. [CrossRef] [PubMed]

21. Shah, A.; Khan, A.M.; Qureshi, R.; Ansari, F.L.; Nazar, M.F.; Shah, S.S. Redox behavior of anticancer chalcone on a glassy carbon electrode and evaluation of its interaction parameters with DNA. Int. J. Mol. Sci. 2008, 9, 1424-1434. [CrossRef] [PubMed]

22. Miranda, C.L.; Stevens, J.F.; Helmrich, A.; Henderson, M.C.; Rodriguez, R.J.; Yang, Y.H.; Deinzer, M.L.; Barnes, D.W.; Buhler, D.R. Antiproliferative and cytotoxic effects of prenylated flavonoids from hops (Humulus lupulus) in human cancer cell lines. Food Chem. Toxicol. 1999, 37, 271-285. [CrossRef]

23. Nowakowska, Z. A review of anti-infective and anti-inflammatory chalcones. Eur. J. Med. Chem. 2007, 42, 125-137. [CrossRef] [PubMed]

24. Zamule, S.M.; Coslo, D.M.; Chen, F.; Omiecinski, C.J. Differentiation of human embryonic stem cells along a hepatic lineage. Chem. Biol. Interact. 2011, 190, 62-72. [CrossRef] [PubMed]

25. Bonzo, J.A.; Ferry, C.H.; Matsubara, T.; Kim, J.; Gonzalez, F.J. Suppression of hepatocyte proliferation by hepatocyte nuclear factor $4 \alpha$ in adult mice. J. Biol. Chem. 2012, 287, 7345-7356. [CrossRef] [PubMed]

26. Alarcón, J.; Alderete, J.; Escobar, C.; Araya, R.; Cespedes, C.L. Aspergillus niger catalyzes the synthesis of flavonoids from chalcones. Biocatal. Biotransform. 2013, 31, 160-167. [CrossRef] 
27. Escobar, C.A.; Trujillo, A.; Howard, J.A.K.; Fuentealba, M. (E)-1-(3-Bromo-phen-yl)-3-(3,4-dimeth-oxy-phenyl)prop-2-en-1-one. Acta Crystallogr. Sect. E. Struct. Rep. Online 2012, 68, o887. [CrossRef] [PubMed]

28. Koiri, R.K.; Trigun, S.K. Dimethyl sulfoxide activates tumor necrosis factor $\alpha-p 53$ mediated apoptosis and down regulates D-fructose-6-phosphate-2-kinase and lactate dehydrogenase-5 in Dalton's lymphoma in vivo. Leuk. Res. 2011, 35, 950-956. [CrossRef] [PubMed]

29. Winter, E.; Chiaradia, L.D.; Silva, A.H.; Nunes, R.J.; Yunes, R.A.; Creczynski-Pasa, T.B. Involvement of extrinsic and intrinsic apoptotic pathways together with endoplasmic reticulum stress in cell death induced by naphthylchalcones in a leukemic cell line: Advantages of multi-target action. Toxicol. In Vitro 2014, 28, 769-777. [CrossRef] [PubMed]

30. Wong, R.S.Y. Apoptosis in cancer: From pathogenesis to treatment. J. Exp. Clin. Cancer Res. 2011, $30,87$. [CrossRef] [PubMed]

31. Elmore, S. Apoptosis: A review of programmed cell death. Toxicol. Pathol. 2007, 35, 495-516. [CrossRef] [PubMed]

32. Conradt, B. Genetic control of programmed cell death during animal development. Annu. Rev. Genet. 2009, 43, 493-523. [CrossRef] [PubMed]

33. Pilatova, M.; Varinska, L.; Perjesi, P.; Sarissky, M.; Mirossay, L.; Solar, P.; Ostro, A.; Mojzis, J. In vitro antiproliferative and antiangiogenic effects of synthetic chalcone analogues. Toxicol. Vitr. 2010, 24, 1347-1355. [CrossRef] [PubMed]

34. Sashidhara, K.V.; Kumar, A.; Kumar, M.; Sarkar, J.; Sinha, S. Synthesis and in vitro evaluation of novel coumarin-chalcone hybrids as potential anticancer agents. Bioorg. Med. Chem. Lett. 2010, 20, 7205-7211. [CrossRef] [PubMed]

35. Kumar, S.K.; Hager, E.; Pettit, C.; Gurulingappa, H.; Davidson, N.E.; Khan, S.R. Design, synthesis, and evaluation of novel boronic-chalcone derivatives as antitumor agents. J. Med. Chem. 2003, 46, 2813-2815. [CrossRef] [PubMed]

36. Shen, K.-H.; Chang, J.-K.; Hsu, Y.-L.; Kuo, P.-L. Chalcone arrests cell cycle progression and induces apoptosis through induction of mitochondrial pathway and inhibition of nuclear factor $\mathrm{\kappa B}$ signalling in human bladder cancer cells. Basic Clin. Pharmacol. Toxicol. 2007, 101, 254-261. [CrossRef] [PubMed]

37. Winter, E.; Chiaradia, L.D.; de Cordova, C.A.S.; Nunes, R.J.; Yunes, R.A.; Creczynski-Pasa, T.B. Naphthylchalcones induce apoptosis and caspase activation in a leukemia cell line: The relationship between mitochondrial damage, oxidative stress, and cell death. Bioorg. Med. Chem. 2010, 18, 8026-8034. [CrossRef] [PubMed]

38. Pereira, C.; Calhelha, R.C.; Barros, L.; Ferreira, I.C.F.R. Antioxidant properties, anti-hepatocellular carcinoma activity and hepatotoxicity of artichoke, milk thistle and borututu. Ind. Crops Prod. 2013, 49, 61-65. [CrossRef]

39. Sikander, M.; Malik, S.; Yadav, D.; Biswas, S.; Katare, D.P.; Jain, S.K. Cytoprotective activity of a trans-chalcone against hydrogen peroxide induced toxicity in hepatocellular carcinoma (HepG2) cells. Asian Pac. J. Cancer Prev. 2011, 12, 2513-2516. [PubMed]

40. Tsai, J.P.; Hsiao, P.C.; Yang, S.F.; Hsieh, S.C.; Bau, D.T.; Ling, C.L.; Pai, C.L.; Hsieh, Y.H. Licochalcone a suppresses migration and invasion of human hepatocellular carcinoma cells through downregulation of MKK4/JNK via NF-KB mediated urokinase plasminogen activator expression. PLoS ONE 2014, 9. [CrossRef] [PubMed]

41. Wu, W.; Ye, H.; Wan, L.; Han, X.; Wang, G.; Hu, J.; Tang, M.; Duan, X.; Fan, Y.; He, S.; et al. Millepachine, a novel chalcone, induces G2/M arrest by inhibiting CDK1 activity and causing apoptosis via ROS-mitochondrial apoptotic pathway in human hepatocarcinoma cells in vitro and in vivo. Carcinogenesis 2013, 34, 1636-1643. [CrossRef] [PubMed]

42. Miccadei, S.; di Venere, D.; Cardinali, A.; Romano, F.; Durazzo, A.; Foddai, M.S.; Fraioli, R.; Mobarhan, S.; Maiani, G. Antioxidative and apoptotic properties of polyphenolic extracts from edible part of artichoke (Cynara scolymus L.) on cultured rat hepatocytes and on human hepatoma cells. Nutr. Cancer 2008, 60, 276-283. [CrossRef] [PubMed]

43. Ghosh, D.; Choudhury, S.T.; Ghosh, S.; Mandal, A.K.; Sarkar, S.; Ghosh, A.; Saha, K.D.; Das, N. Nanocapsulated curcumin: Oral chemopreventive formulation against diethylnitrosamine induced hepatocellular carcinoma in rat. Chem. Biol. Interact. 2012, 195, 206-214. [CrossRef] [PubMed] 
44. Park, C.-S.; Ahn, Y.; Lee, D.; Moon, S.W.; Kim, K.H.; Yamabe, N.; Hwang, G.S.; Jang, H.J.; Lee, H.; Kang, K.S.; et al. Synthesis of apoptotic chalcone analogues in HepG2 human hepatocellular carcinoma cells. Bioorg. Med. Chem. Lett. 2015, 25, 5705-5707. [CrossRef] [PubMed]

45. Abu, N.; Akhtar, M.N.; Yeap, S.K.; Lim, K.L.; Ho, W.Y.; Zulfadli, A.J.; Omar, A.R.; Sulaiman, M.R.; Abdullah, M.P.; Alitheen, N.B. Flavokawain a induces apoptosis in MCF-7 and MDA-MB231 and inhibits the metastatic process in vitro. PLoS ONE 2014, 9, e105244. [CrossRef] [PubMed]

46. Deb Majumdar, I.; Devanabanda, A.; Fox, B.; Schwartzman, J.; Cong, H.; Porco, J.A.; Weber, H.C. Synthetic cyclohexenyl chalcone natural products possess cytotoxic activities against prostate cancer cells and inhibit cysteine cathepsins in vitro. Biochem. Biophys. Res. Commun. 2011, 416, 397-402. [CrossRef] [PubMed]

47. Tang, Y.; Simoneau, A.R.; Xie, J.; Shahandeh, B.; Zi, X. Effects of the kava chalcone flavokawain A differ in bladder cancer cells with wild-type versus mutant p53. Cancer Prev. Res. 2008, 1, 439-451. [CrossRef] [PubMed]

48. Arianingrum, R.; Sunarminingsih, R.; Meiyanto, E.; Mubarika, S. Potential of a Chalcone Derivate Compound as Cancer Chemoprevention in Breast Cancer. In Proceedings of the 2012 3rd International Conference on Chemistry and Chemical Engineering IPCBEE, Singapore, 29-30 June 2012; Volume 38, pp. 41-45.

49. Singh, N.; Sarkar, J.; Sashidhara, K.V.; Ali, S.; Sinha, S. Anti-tumour activity of a novel coumarin-chalcone hybrid is mediated through intrinsic apoptotic pathway by inducing PUMA and altering Bax/Bcl-2 ratio. Apoptosis 2014, 19, 1017-1028. [CrossRef] [PubMed]

50. Kamada, S.; Kikkawa, U.; Tsujimoto, Y.; Hunter, T. Nuclear translocation of caspase-3 is dependent on its proteolytic activation and recognition of a substrate-like protein(s). J. Biol. Chem. 2005, 280, 857-860. [CrossRef] [PubMed]

51. Raisova, M.; Hossini, A.M.; Eberle, J.; Riebeling, C.; Wieder, T.; Sturm, I.; Daniel, P.T.; Orfanos, C.E.; Geilen, C.C. The Bax/Bcl-2 ratio determines the susceptibility of human melanoma cells to CD95/Fas-mediated apoptosis. J. Investig. Dermatol. 2001, 117, 333-340. [CrossRef] [PubMed]

52. Yang, E.; Zha, J.; Jockel, J.; Boise, L.H.; Thompson, C.B.; Korsmeyer, S.J. Bad, a heterodimeric partner for Bcl-XL and Bcl-2, displaces Bax and promotes cell death. Cell 1995, 80, 285-291. [CrossRef]

53. Tamm, I.; Schriever, F.; Dörken, B. Apoptosis: Implications of basic research for clinical oncology. Lancet Oncol. 2001, 2, 33-42. [CrossRef]

54. Liu, G. Effects of apoptosis-related proteins caspase-3, Bax and Bcl-2 on cerebral ischemia rats. Biomed. Rep. 2013, 1, 861-867. [CrossRef] [PubMed]

55. Yang, B.; Johnson, T.S.; Thomas, G.L.; Watson, P.F.; Wagner, B.; Furness, P.N.; El Nahas, A.M. A shift in the Bax/Bcl-2 balance may activate caspase-3 and modulate apoptosis in experimental glomerulonephritis. Kidney Int. 2002, 62, 1301-1313. [CrossRef] [PubMed]

56. Handayani, T.; Sakinah, S.; Nallappan, M.; Pihie, A.H.L. Regulation of p53-, Bcl-2- and caspase-dependent signaling pathway in xanthorrhizol-induced apoptosis of HepG2 hepatoma cells. Anticancer Res. 2007, 27, 965-971. [PubMed]

57. Azad, M.B.; Chen, Y.; Gibson, S.B. Regulation of autophagy by reactive oxygen species (ROS): Implications for cancer progression and treatment. Antioxid. Redox Signal. 2009, 11, 777-790. [CrossRef] [PubMed]

58. Simon, H.U.; Haj-Yehia, A.; Levi-Schaffer, F. Role of reactive oxygen species (ROS) in apoptosis induction. Apoptosis 2000, 5, 415-418. [CrossRef] [PubMed]

59. Syam, S.; Abdelwahab, S.I.; Al-Mamary, M.A.; Mohan, S. Synthesis of chalcones with anticancer activities. Molecules 2012, 17, 6179-6195. [CrossRef] [PubMed]

60. Belsare, D.P.; Pal, S.C.; Kazi, A.A.; Kankate, R.S.; Vanjari, S.S. Evaluation of antioxidant activity of chalcones and flavonoids. Int. J. ChemTech Res. 2010, 2, 1080-1089.

61. Singh, S.; Sharma, P.K.; Kumar, N.; Dudhe, R. Anti-oxidant Activity of 2-hydroxyacetophenone Chalcone. J. Adv. Sci. Res. 2011, 2, 37-41.

62. Anto, R.J.; Sukumaran, K.; Kuttan, G.; Rao, M.N.; Subbaraju, V.; Kuttan, R. Anticancer and antioxidant activity of synthetic chalcones and related compounds. Cancer Lett. 1995, 97, 33-37. [CrossRef]

63. Shenvi, S.; Kumar, K.; Hatti, K.S.; Rijesh, K.; Diwakar, L.; Reddy, G.C. Synthesis, anticancer and antioxidant activities of 2,4,5-trimethoxy chalcones and analogues from asaronaldehyde: Structure-activity relationship. Eur. J. Med. Chem. 2013, 62, 435-442. [CrossRef] [PubMed] 
64. Clippinger, A.J.; Bouchard, M.J. Hepatitis B virus HBx protein localizes to mitochondria in primary rat hepatocytes and modulates mitochondrial membrane potential. J. Virol. 2008, 82, 6798-6811. [CrossRef] [PubMed]

65. Institute of Laboratory Animal Resources Committee. Guide for the Care and Use of Laboratory Animals; The National Academies Press: Washington, DC, USA, 2011.

66. Hempel, S.L.; Buettner, G.R.; O'Malley, Y.Q.; Wessels, D.A.; Flaherty, D.M. Dihydrofluorescein diacetate is superior for detecting intracellular oxidants: Comparison with $2^{\prime}, 7^{\prime}$-dichlorodihydrofluorescein diacetate, 5(and 6)-carboxy-2', $7^{\prime}$-dichlorodihydrofluorescein diacetate, and dihydrorhodamine 123 . Free Radic. Biol. Med. 1999, 27, 146-159. [CrossRef]

67. Echeverría, C.; Montorfano, I.; Cabello-Verrugio, C.; Armisén, R.; Varela, D.; Simon, F. Suppression of transient receptor potential melastatin 4 expression promotes conversion of endothelial cells into fibroblasts via transforming growth factor/activin receptor-like kinase 5 pathway. J. Hypertens. 2015, 33, 981-992. [CrossRef] [PubMed]

68. Nuñez-Villena, F.; Becerra, A.; Echeverría, C.; Briceño, N.; Porras, O.; Armisén, R.; Varela, D.; Montorfano, I.; Sarmiento, D.; Simon, F. Increased expression of the transient receptor potential melastatin 7 channel is critically involved in lipopolysaccharide-induced reactive oxygen species-mediated neuronal death. Antioxid. Redox Signal. 2011, 15, 2425-2438. [CrossRef] [PubMed]

69. Echeverría, C.; Becerra, A.; Nuñez-Villena, F.; Muñoz-Castro, A.; Stehberg, J.; Zheng, Z.; Arratia-Perez, R.; Simon, F.; Ramírez-Tagle, R. The paramagnetic and luminescent $\left[\operatorname{Re}_{6} \mathrm{Se}_{8} \mathrm{I}_{6}\right]^{3-}$ cluster. Its potential use as an antitumoral and biomarker agent. New J. Chem. 2012, 36, 927. [CrossRef]

70. Villota, C.; Campos, A.; Vidaurre, S.; Oliveira-Cruz, L.; Boccardo, E.; Burzio, V.A.; Varas, M.; Villegas, J.; Villa, L.L.; Valenzuela, P.D.T.; et al. Expression of mitochondrial non-coding RNAs (ncRNAs) is modulated by high risk human papillomavirus (HPV) oncogenes. J. Biol. Chem. 2012, 287, 21303-21315. [CrossRef] [PubMed]

(C) 2016 by the authors; licensee MDPI, Basel, Switzerland. This article is an open access article distributed under the terms and conditions of the Creative Commons by Attribution (CC-BY) license (http:/ / creativecommons.org/licenses/by/4.0/). 